\title{
Treatment outcome of thalidomide based regimens in newly diagnosed and relapsed/ refractory non-transplant multiple myeloma patients: a single center experience from Thailand
}

\author{
Pimjai Niparuck, Ladda Sorakhunpipitkul, Vichai Atichartakarn, Suporn Chuncharunee, Artit Ungkanont, \\ Pantep Aungchaisuksiri, Teeraya Puavilai, Saengsuree Jootar
}

\begin{abstract}
Background: Thalidomide based regimen is an effective and well tolerated therapy in multiple myeloma (MM) patients, however, there were a small number of studies written about the results of thalidomide therapy in nontransplant MM patients. We therefore conducted a retrospective study of 42 consecutive patients with newly diagnosed and relapsed/refractory MM treated with thalidomide- based induction regimens followed by thalidomide maintenance therapy.

Results: Induction regimens with thalidomide and dexamethasone, and the oral combination of melphalan, prednisolone and thalidomide were administrated in 22 and 16 patients, respectively. The remaining 4 patients received other thalidomide- containing regimens. Twenty-nine patients received thalidomide as a salvage regimen. Twenty-three out of 26 patients achieving complete remission (CR) and very good partial remission (VGPR) received thalidomide maintenance. Of the 41 evaluable patients, median time of treatment was 21 months (3- 45 months), ORR was $92.7 \%$ with a $63.4 \%$ CRNGPR. With a median follow up of 23 months, 3-year- PFS and 3-year-OS were 58.6 and $72.6 \%$, respectively. Median time to progression was 42 months. While 3-year-PFS and 3-year-OS in non-transplant patients receiving thalidomide maintenance therapy were 67 and 80\%, respectively.

Conclusions: Prolonged thalidomide therapy enhanced survival rate and less frequently developed serious toxicity in non-transplant multiple myeloma patients.
\end{abstract}

To the editor:

Thalidomide based therapy for multiple myeloma $(\mathrm{MM})$ improves the response and the complete remission $(\mathrm{CR})$ rates in previously untreated and relapsed/ refractory MM (overall response rate was $48-73 \%$ with a $5-10 \%$ CR) $[1,2]$. In this study, we performed a retrospective study of 42 newly diagnosed and relapsed/ refractory MM patients treated with thalidomide based regimens without upfront ASCT at Ramathibodi Hospital during January 2005-October 2008. Thirteen and 29

\footnotetext{
* Correspondence: niparuckblue@gmail.com
Division of hematology, Department of Medicine, Ramathibodi Hospital,

* Correspondence: niparuckblue@gmail.com Mahidol University, Thailand
}

patients were previously untreated and relapsed/refractory MM, respectively (Table 1 ). Twenty-two patients received thalidomide $200 \mathrm{mg}$ /day and oral dexamethasone $20-40 \mathrm{mg} /$ day $(\mathrm{d} 1-4)$ every 2 weeks, 16 patients received oral melphalan $4 \mathrm{mg} / \mathrm{m}^{2} /$ day (d1-7), prednisolone $40 \mathrm{mg} / \mathrm{m}^{2} /$ day (d1-7) and thalidomide $100 \mathrm{mg} /$ day every 4 weeks, 3 patients received thalidomide 200-400 $\mathrm{mg} /$ day and the remaining 1 patient received thalidomide $100 \mathrm{mg} /$ day, pegylated liposomal doxorubicin i.v. $40 \mathrm{mg} / \mathrm{m}^{2} /$ day (d1) and oral dexamethasone $40 \mathrm{mg} /$ day (d1-4, 9-12) every 4 weeks. Eighty-eight percents (23/26 patients) achieving CR/VGPR (very good partial remission) received thalidomide maintenance therapy (100- 
$200 \mathrm{mg} /$ day). Aspirin $65-325 \mathrm{mg} /$ day or warfarin 1.5 $\mathrm{mg} /$ day was given to all patients for deep vein thrombosis prophylaxis. Of the 41 evaluable patients, median treatment period was 21 months $(3-45 \mathrm{~m})$. The ORR (overall response rate) was $92.7 \%$, with a $63.4 \% \mathrm{CR} /$ VGPR. Median number of courses to achieve PR and CR/VGPR were 4 (range, 2-13) and 6 courses (range, 2$16)$, respectively. There was no difference in ORR and CR between frontline and salvage therapy groups (92.3\% vs $93 \%)$ and (39\% vs $23 \%)$, respectively. The ORR and CR rate for those treated with thal/dex were slightly higher than those treated with MPT $(95.2 \%$ vs $87.5 \%$ and $38 \%$ vs $25 \%$ ). Median follow up was 23 months, 3 -
year-OS and 3-year-PFS were 72.6 and $58.6 \%$, respectively. Median TTP was 42 months, non- VGPR/CR patients had significant poorer PFS by multivariate analysis $(p=0.01)$ and non-responders had significant shorter OS $(p=0.01)$. In maintenance group, median treatment duration was 14 months $(4-37 \mathrm{~m})$. Threeyear-PFS and 3-year-OS were 67 and $80 \%$, respectively. Toxicities were constipation (81\%), neuropathy (67\%), muscle weakness in the legs (5\%), infection (7\%) and thrombosis (5\%). New agents for treatment of MM with no planned ASCT show the CR/VGPR rates of $50-80 \%$ with a PFS of 2 years [3-5]. The CR/VGPR rates in our patients were also high that might be associated with a

Table 1 Patients' characteristics and treatment outcomes of previously untreated and relapsed/refractory multiple myeloma

\begin{tabular}{|c|c|c|c|c|c|c|c|c|c|c|c|}
\hline \multirow[b]{2}{*}{ Characteristics } & \multirow[b]{2}{*}{ Total patients $(\mathrm{N}=42)$} & \multicolumn{2}{|c|}{ ORR } & \multicolumn{2}{|c|}{ CR/VGPR } & \multicolumn{3}{|c|}{ PFS } & \multicolumn{3}{|c|}{ os } \\
\hline & & $\begin{array}{c}\text { No. of } \\
\text { Patients } \\
\%\end{array}$ & $\overline{p \text {-value }}$ & $\begin{array}{c}\text { No. of } \\
\text { patients }\end{array}$ & $\overline{p \text {-value }}$ & HR & $95 \% \mathrm{Cl}$ & $\overline{p \text {-value }}$ & HR & $95 \% \mathrm{Cl}$ & p-value \\
\hline $\begin{array}{l}\text { Age (years), } \\
\text { median (range) }\end{array}$ & $62,(36-75)$ & & & & & & & & & & \\
\hline$\leq 60$ & 17 & 15(94) & 0.83 & $9(56.3)$ & 0.45 & 2.95 & $0.98-8.81$ & 0.05 & 0.81 & $0.09-7.27$ & 0.85 \\
\hline$>60$ & 25 & 23(92) & & $17(68)$ & & & & & & & \\
\hline \multicolumn{12}{|l|}{ Sex } \\
\hline Male & 21 & 18(85.7) & 0.79 & $13(65)$ & 0.91 & 0.77 & $0.25-2.38$ & 0.65 & 2.06 & $0.34-12.68$ & 0.44 \\
\hline Female & 21 & $20(95.2)$ & & $14(66.7)$ & & & & & & & \\
\hline \multicolumn{12}{|l|}{ Prior treatment } \\
\hline Yes & 29 & 26(92.6) & 0.95 & 19(67.9) & 0.69 & 3.68 & $0.91-10.28$ & 0.06 & 0.87 & $0.96-7.88$ & 0.9 \\
\hline No & 13 & 12(92.3) & & $8(61.5)$ & & & & & & & \\
\hline \multicolumn{12}{|l|}{$\begin{array}{l}\text { International } \\
\text { staging system }\end{array}$} \\
\hline I, II & 8,18 & 24(92.3) & 0.97 & $15(57.7)$ & 0.93 & 6.30 & $0.73-54.01$ & 0.09 & 2.22 & $0.20-24.57$ & 0.51 \\
\hline III & 13 & $12(92.3)$ & & $8(61.5)$ & & & & & & & \\
\hline No data & 3 & & & & & & & & & & \\
\hline \multicolumn{12}{|l|}{ M-protein subtype } \\
\hline $\lg G, \lg A, \lg M$ & $23,8,1$ & $27(87.1)$ & 0.32 & 19(61.3) & 0.86 & 3.19 & $0.64-15.91$ & 0.16 & 1.21 & $0.13-11.65$ & 0.87 \\
\hline Kappa, Lamda & 3,6 & $9(100)$ & & $6(66.7)$ & & & & & & & \\
\hline Unknown type & 1 & & & & & & & & & & \\
\hline \multicolumn{12}{|l|}{$\begin{array}{l}\text { Serum creatinine } \\
\text { level }\end{array}$} \\
\hline$<2 \mathrm{mg} / \mathrm{dl}$ & 34 & $31(91.2)$ & 0.43 & $22(64.7)$ & 0.57 & 0.74 & $0.08-6.72$ & 0.79 & 0.03 & $0.01-856.9$ & 0.50 \\
\hline$\geq 2 \mathrm{mg} / \mathrm{dl}$ & 8 & $7(100)$ & & $4(57.2)$ & & & & & & & \\
\hline \multicolumn{12}{|l|}{$\begin{array}{l}\text { Serum } \beta 2 \text { M level, } \\
\mu \mathrm{g} / \mathrm{ml}\end{array}$} \\
\hline$\leq 5$ & 26 & $24(92.3)$ & 0.53 & $17(65.4)$ & 0.79 & 4.89 & $0.55-43.88$ & 0.16 & 1.97 & $0.18-21.81$ & 0.58 \\
\hline$>5$ & 13 & $11(84.6)$ & & $8(61.5)$ & & & & & & & \\
\hline No data & 3 & & & & & & & & & & \\
\hline \multicolumn{12}{|l|}{$\begin{array}{l}\text { Response to } \\
\text { treatment }\end{array}$} \\
\hline Yes & 38 & - & - & - & - & 0.15 & $0.04-0.61$ & 0.01 & 0.03 & $0.01-0.35$ & 0.01 \\
\hline No & 3 & & & & & & & & & & \\
\hline \multicolumn{12}{|l|}{ CR/NGPR } \\
\hline Yes & 26 & - & - & - & - & 0.14 & $0.04-0.47$ & 0.01 & 0.21 & $0.03-1.48$ & 0.12 \\
\hline No & 15 & & & & & & & & & & \\
\hline
\end{tabular}


prolonged use of thalidomide induction. Thalidomide maintenance in CR/VGPR patients provided impressive survival benefit. Hence, thalidomide is an effective therapy for MM and prolonged thalidomide use had the survival benefit and had minimal serious toxicity in non-transplant MM patients. To date, MM remains incurable. Novel agents continue to be developed and are eagerly awaited [5-7].

Received: 14 December 2009

Accepted: 5 January 2010 Published: 5 January 2010

\section{References}

1. David DS, Vincent R, Grzegorz SN, Morie AG, Angela D, Martha QL,

Suzanne H, Rafael F, John AL, Robert AK, Philip RG, Thomas EW:

Combination therapy with thalidomide and dexamethasone in patients with newly diagnosed multiple myeloma not undergoing upfront autologous stem cell transplantation: a phase II trial, haematologica. 2005, 90:1650-54.

2. Rajkumar SV, Hayman S, Gertz MA, Dispenzieri A, Lacy MQ, Greipp PR, Geyer S, Iturria N, Fonseca R, Lust JA, Kyle RA, Witzig TE: Combination therapy with thalidomide plus dexamethasone for newly diagnosed myeloma. J Clin Oncol 2002, 20:4319-23.

3. Palumbo A, Bringhen S, Caravita T, Merla E, Capparella V, Callea V, Cangialosi C, Grasso M, Rossini F, Galli M, Catalano L, Zamagni E,

Petrucci MT, De stefano V, Ceccarelli M, Ambrosini MT, Avonto I, Falco P, Ciccone G, Liberati AM, Musto P, Boccadoro M: Oral melphalan and prednisone chemotherapy plus thalidomide compared with melphalan and prednisone alone in elderly patients with multiple myeloma: randomized controlled trial. Lancet 2006, 367:825-35.

4. Facon T, Mary JY, Hulin C, Benboubker L, Attal M, Pegourie B, Renaud M, Harousseau JL, Guillerm G, Chaleteix C, Dib M, Voillat L, Maisonneuve H, Troncy J, Dorvaux V, Monconduit M, Martin C, Casassus P, Jaubert J, Jardel H, Doyen C, Kolb B, Anglaret B, Grosbois B, Yakoub-Agha I, Mathiot C, Avet-Loiseau H: Melphalan and prednisone plus thalidomide versus melphalan and prednisone, or reduced-intensity autologous stem cell transplantation in elderly patients with multiple myeloma (IFM 99-06): a randomized trial. Lancet 2007, 370:1209-18.

5. Kotla V, Goel S, Nischal S, Heuck C, Vivek K, Das B, Verma A: Mechanism of action of lenalidomide in hematological malignancies. $J$ Hematol Oncol 2009, 2:36.

6. Cang S, Ma Y, Liu D: New clinical developments in histone deacetylase inhibitors for epigenetic therapy of cancer. J Hematol Oncol 2009, 2:22.

7. Siegel D, Hussein M, Belani C, Robert F, Galanis E, Richon VM, GarciaVargas J, Sanz-Rodriguez C, Rizvi S: Vorinostat in solid and hematologic malignancies. J Hematol Oncol 2009, 2:31.

doi:10.1186/1756-8722-3-1

Cite this article as: Niparuck et al:: Treatment outcome of thalidomide based regimens in newly diagnosed and relapsed/refractory nontransplant multiple myeloma patients: a single center experience from Thailand. Journal of Hematology \& Oncology 2010 3:1.
Publish with Biomed Central and every scientist can read your work free of charge

"BioMed Central will be the most significant development for disseminating the results of biomedical research in our lifetime. "

Sir Paul Nurse, Cancer Research UK

Your research papers will be:

- available free of charge to the entire biomedical community

- peer reviewed and published immediately upon acceptance

- cited in PubMed and archived on PubMed Central

- yours - you keep the copyright 